\title{
Assessment of structural reliability of precast concrete buildings
}

\author{
Alexandr Koyankin ${ }^{1, *}$, and Valeriy Mitasov ${ }^{2}$ \\ ${ }^{1}$ Siberian Federal University, 660041 Krasnoyarsk, Russia \\ ${ }^{2}$ Novosibirsk State University of Architecture and Civil Engineering, 630008 Novosibirsk, Russia
}

\begin{abstract}
Precast housing construction is currently being under rapid development, however, reliability of building structures made from precast reinforced concrete cannot be assessed rationally due to insufficient research data on that subject. In this regard, experimental and numerical studies were conducted to assess structural reliability of precast buildings as described in the given paper. Experimental studies of full-scale and model samples were conducted; numerical studies were held based on finite element models using "Lira" software. The objects under study included fragment of flooring of a building under construction, full-size fragment of flooring, full-scale models of precast cross-beams-to-columns joints and joints between hollow-core floor slabs and precast and cast-inplace cross-beams. Conducted research enabled to perform an objective assessment of structural reliability of precast buildings.
\end{abstract}

\section{Introduction}

Precast construction is rapidly developing all over the world due to its ability of combining the advantages of precast and cast-in-place housing construction at the highest possible minimizing of its drawbacks. In particular, well-known Saret construction system suggested by French builders in the middle of the XXth century is being used by construction companies of the world (France, Russia, Czech Republic, Great Britain, French-speaking countries of Africa, etc.). The system underwent some structural changes depending on natural and climatic, seismic, regulatory and other peculiar features of the regions [1-8].

Popularity of precast housing construction defines the relevance of conducting research devoted to specific aspects of precast structures deformation. Scientists from many countries conducted various studies; e.g. the frame of B1.020.1-7 series (Russian grade) was multiply subjected to field tests on buildings under construction [9-11]. The study [12] describes experimental testing of load bearing capacity of the standard slabs along normal and oblique section with regard to their special work by supporting on three sides or flat loading of flooring. Professor A.S. Semchenkov conducted experimental study of RADIUSS frame $[13,14]$ that proved its effectiveness. Testing of precast flooring with wide cross-beams was described in [15].

The analysis of previous research demonstrated that the amount of research, namely experimental ones, is insufficient for assessing structural reliability of precast frame made

\footnotetext{
* Corresponding author: koyankinaa@mail.ru
} 
with precast cross-beams and hollow-core slabs supported on them. Therefore, the present paper is aimed at assessing structural reliability of precast frame of Saret type.

Field tests were conducted on flooring segment and fragment of precast frame; testing of full-scale models of precast cross-beams-to-columns joints was performed; hollow-core floor slabs to precast and cast-in-place cross-beams joints were tested; numerical simulation was conducted on models of slab to flooring joints and cross-beam to column joints.

\section{Experimental}

Researchers of Institute of Engineering and Construction, Siberian Federal University (Krasnoyarsk, Russia) together with the research group of Novosibirsk State University of Architecture and Civil Engineering (Novosibirsk, Russia) conducted a series of experimental and numerical studies aimed at defining the stress-strain state of the frame mentioned above $[16,17]$. Part of the flooring mesh on the first floor of a building under construction No. 1 of the II Residential area Pokrovskii in Krasnoyarsk was subjected to field tests; mesh size for testing was equal to $6.0 \times 7.2 \mathrm{~m}$ in plan view (Fig. 1). The testing included four-stage loading of the mentioned fragment of flooring by covering it with ceramic bricks up to the loading of $400 \mathrm{~kg} / \mathrm{m}^{2}$. In these conditions we could observe fixation of flooring deflection and possible shear of cross-beams with reference to columns.
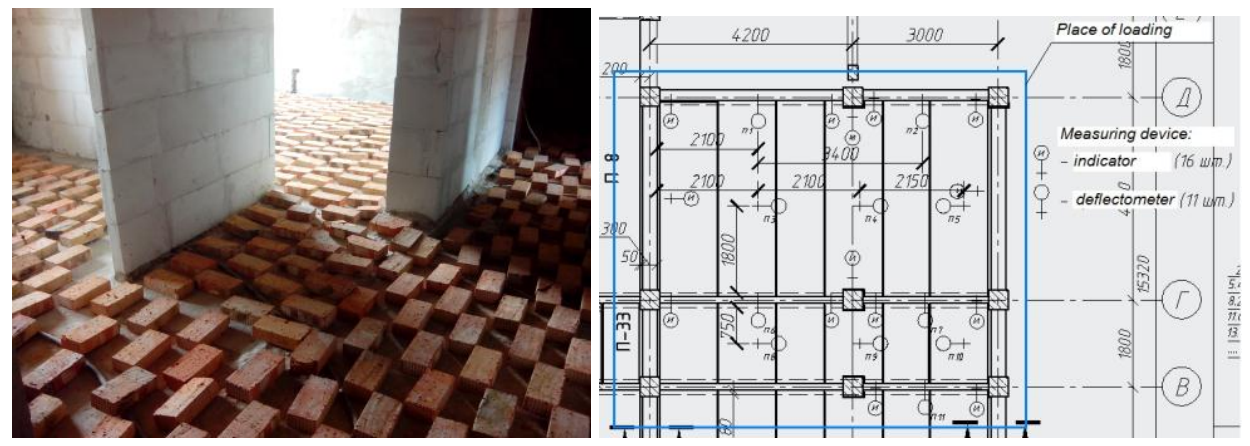

Fig. 1. Fragment of flooring of a building under construction.

Field tests were conducted on a fragment of precast frame sized 6430x4940x2800(h) mm, mounted and tested at the factory "Monolitresurs", LLC based in Krasnoyarsk (Fig. 2). The loading was conducted within four stages, by covering it with solid foundation blocks and precast cross-beams. The maximum load on the balcony was $6.06 \mathrm{kN} / \mathrm{m}^{2}$ on the floor area $0.8 \mathrm{~m}$ wide from the balcony edge; the load acting on the flooring was $5.60 \mathrm{kN} / \mathrm{m}^{2}$. Flooring deflections of the structural elements were defined by means of deflectometers and indicators, while the strain was recorded using universal multi-channel measuring-recording device TEPEM-4.0 with displacement sensors DLP-10. 

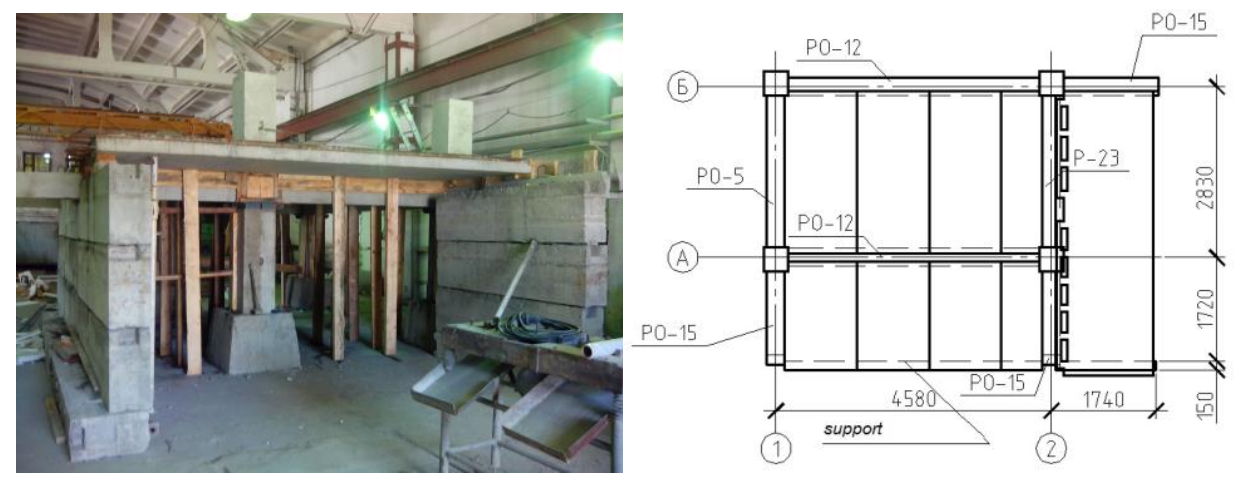

Fig. 2. Fragment of precast frame.

Moreover, four full-scale models of joints between precast cross-beam and column were tested in the Structures Testing Laboratory of Siberian Federal University (Fig. 3). Overall dimensions of models enabled to obtain $\mathrm{M}$ and $\mathrm{Q}$ stresses combination in the joint corresponding to the stress state of the joint in $6 \mathrm{~m}$ spans and larger. Samples were tested using specially developed test bench mounted in the "streams" of strong floor of the testing laboratory. Meanwhile, the loading of test samples mounted directly on the strong floor was provided by two 100-tons jacks DU100P150 (Russian grade) placed on the edges of samples consoles and transmitting top-down load. Vertical displacements were measured by indicators and deflectometers, while deformations - by the measuring system MMTC-64 with resistance strain gauges KF5P1-50-120-A-12 (concrete) and KF5P1-10-200-A-12 (reinforcement). The width of cracks opening was defined by the microscope MPB-3. In addition to experimental research using Lira software complex numerical simulation of the above mentioned models was conducted using solid finite elements for concrete and rod finite elements for reinforcement.

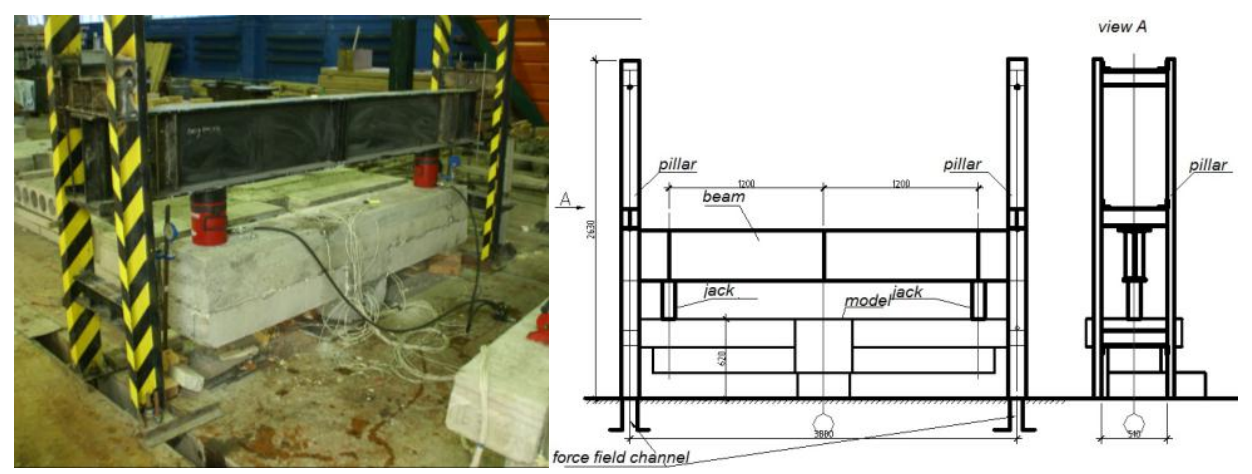

Fig. 3. Testing of cross-beam to column joints.

Another testing included three joints between hollow-core floor slab and precast and cast-in-place cross-beam (Fig. 4). Testing was held using test bench mounted in the "streams" of power floor of the testing laboratory. The load was applied top-down by two 100 -tons jacks DU100P150, placed on the edges of samples consoles and transmitting vertical load. Deflections were defined by deflectometers and indicators, while strain was defined by the measuring system MMTC-64. Numerical studies were conducted in a similar way to finite element models of cross-beam to column joints. 


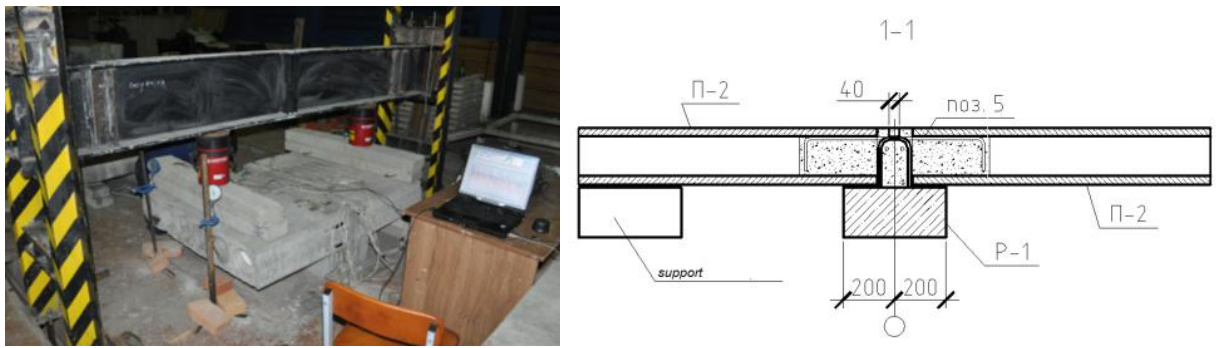

Fig. 4. Testing of joints between hollow-core slab and cross-beam.

\section{Results}

Structural solution of precast frame under study provides the necessary load bearing capacity as required by technical prescriptions, also the required stiffness and crack resistance to the full extent. However, experimental data highlight the necessity to perform a number of structural technical solutions enabling to provide larger structural reliability of precast frame and further reduction of construction costs.

Detailed analysis of the data obtained from the studies makes it possible to conclude that the rigidity of structure of precast flooring is provided with measurable reserve. This became possible due to quite high bending stiffness and, at the same time, light weight of hollow-core floor slab, as well as due to the fact that slabs and cross-beams were prestressed. Moreover, additional bending stiffness is provided by key joint of hollow-core slab with precast cross-beam, causing their joint deformation.

In all conducted tests deflections did not reach the admissible limit values. Particularly, vertical displacements on field tests on a building under construction and frame fragment hardly exceeded $1 \mathrm{~mm}$ (deflection in the center of fragment mesh of pre-fabricated frame was $1.03 \mathrm{~mm}$ with the load of $400 \mathrm{~kg} / \mathrm{m}^{2}$ ). Along with that, the values of deflections obtained by using the calculation methodology suggested by regulatory documents and as a result of numerical studies using Lira software were $0.81 \mathrm{~mm}$ and $0.82 \mathrm{~mm}$ respectively.

Experimental study of cross-beam to column joints demonstrated the maximum value of deflection $14.4 \mathrm{~mm}$ with the load of $41 \mathrm{kN}$ in the joints without hollow-core slabs and 8.5 $\mathrm{mm}$ in the joints with fragments of slabs. This testifies that inclusion of hollow-core slabs into combined deformation with cross-beam has a significant influence on bending stiffness (causes its increase) of the cross-beam. As can be seen from numerical studies, the maximum deflections defined on the edges of cross-beams were $11.1 \mathrm{~mm}$ with the load of $41 \mathrm{kN}$, i.e. the difference between the obtained experimental and numerical data (Fig. 5) did not exceed $23 \%$, thus validating the obtained results.
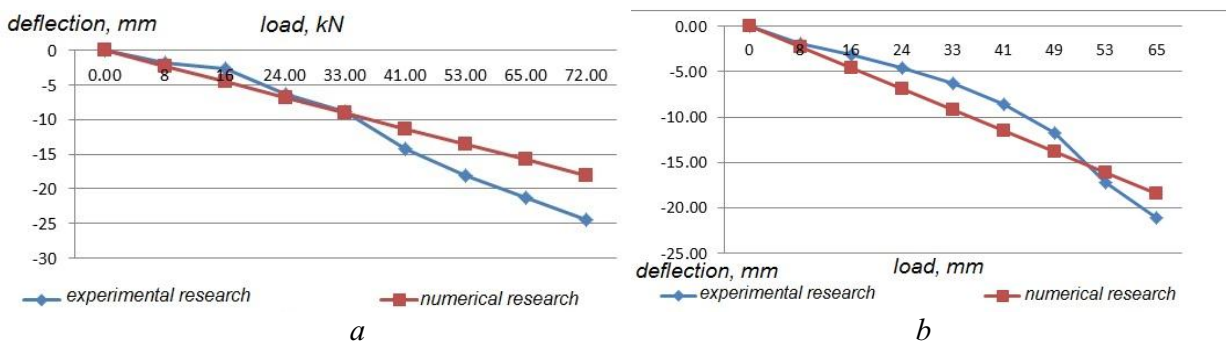

Fig. 5. Deflection curve: $a$-samples with fragment of hollow-core slabs; $b$-samples without fragment of hollow-core slabs. 
Crack resistance of the precast frame structure corresponds to the requirements of rules and regulations of the Russian Federation. Particularly, during field tests on a building under construction and fragment of the building frame no cracks were observed at the experimental load on the flooring of $4 \mathrm{kN} / \mathrm{m}^{2}$ and $5.6 \mathrm{kN} / \mathrm{m}^{2}$ respectively (results of straingauge measurement showing that tensile strain of concrete did not exceed the limit value of 0.0001 indirectly proved the absence of cracks).

The absence of cracks during experimental loading was also proved by theoretical calculations demonstrating that in hollow-core slab the cracks must occur with the load of $27.2 \mathrm{kN} / \mathrm{m}^{2}$ applied to the flooring, while in precast cross-beam (in the solid part on the support) it should be the load of $13.7 \mathrm{kN} / \mathrm{m}^{2}$. During experimental research of cross-beam to column joints only normal cracks (the width of opening $0.2 \ldots 0.3 \mathrm{~mm}$, which does not exceed the admissible limit value) were registered in cast-in-place reinforced concrete in cross-beam-to-column joints.

It should also be noted that along with the positive influence of slab to cross-beam key joint on increasing the cross-beam stiffness, also the negative influence of hollow-core slab inclusion into combined deformation with the cross-beam was observed. In this case hollow-core slab starts to bend in lateral non-operating direction with further formation of longitudinal cracks. This was recorded during testing of the cross-beam to column joint.

The picture of crack formation obtained from experiments was also proved by stress isofields obtained during numerical studies (Fig. 6). Particularly, the maximum tensile stresses in precast cross-beam reaching the limit value of $1.05 \mathrm{MPa}$ were concentrated in the place of joining between the cross-beam and the column, in the exact place where cracks formation was observed during experiment. The lower compression zone keeps its load bearing capacity where the maximum tensile stresses did not exceed 12.9 $\mathrm{MPa}$. Moreover, occurrence of longitudinal crack in the hollow-core floor slab which is included into operation of cross-beam under bending due to key joint was proved by numerical studies as appearing of ultimate tensile stresses in the slab in lateral non-operating direction for the slab.

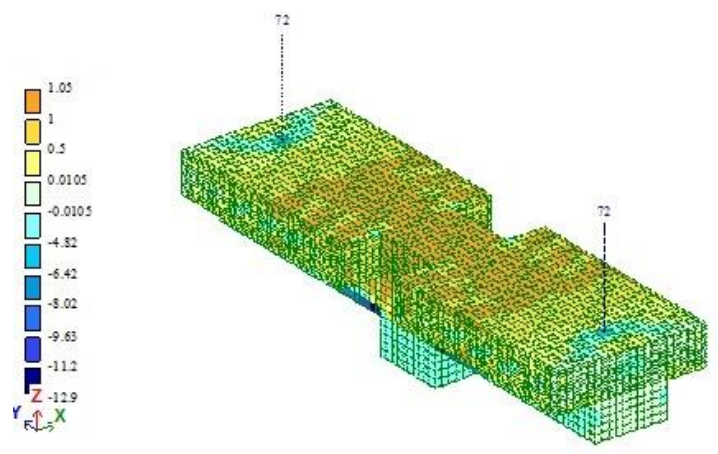

Fig. 6. Stress isofields (MPa) of the sample with fragments of hollow-core slabs.

In spite of the fact that during field tests on a building under construction and fragment of building frame the structures were not subject to complete fracture, still quite high load bearing capacity of precast frame can be inferred according to the following features, as defined from experimental studies:

- the load reached the reference value;

- the signs of failure were not visually observed;

- the value of tensile strain defined in the place of sensors placement did not exceed the admissible limit value equal to 0.002 ; 
- calculation of load-bearing capacity according to standards of the Russian Federation showed that admissible load on the hollow-core slab was $16.8 \mathrm{kN} / \mathrm{m}^{2}$, while fracture of precast cross-beam requires load of $59.4 \mathrm{kN} / \mathrm{m}^{2}$ acting on the flooring.

Unlike the field tests, cross-beam to column joints were subject to fracture occurring under the load of $65-73 \mathrm{kN}$; that testifies on the high load bearing capacity of the joints (load bearing capacity defined in technical regulations is $60 \mathrm{kN}$ ). The depletion of loadbearing capacity occurred due to reaching the yield stress of $400 \mathrm{MPa}$ in longitudinal reinforcement, the value was recorded by strain-gauge sensors. Fracture of compression zone of concrete resulting from experiment did not occur, as seen from visual examination, and also from the data of strain-gauge measurement that did not record the ultimate strain of compressed concrete (Fig. 7).

Similar results were shown by numerical studies, where the stresses in longitudinal reinforcement reached the limit values of $400 \mathrm{MPa}$, while the maximum tensile stresses in concrete were 12.9 MPa.

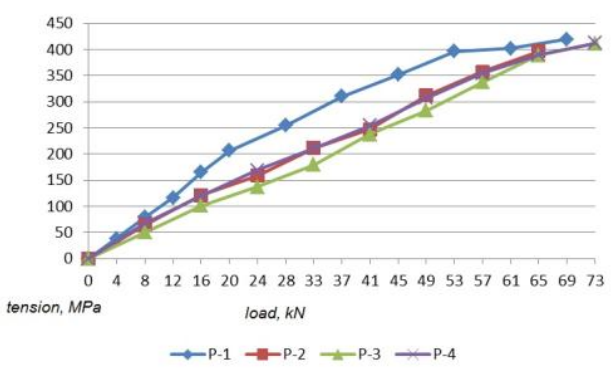

$a$

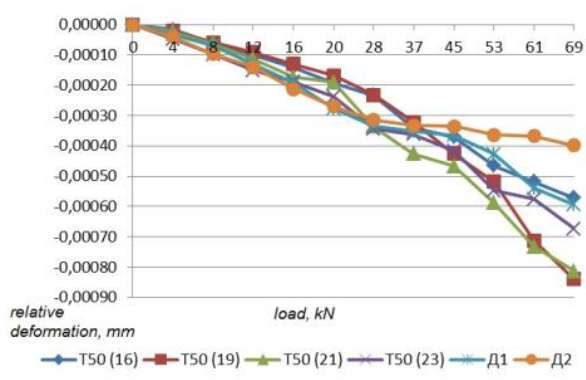

$b$

Fig. 7. The readings of strain-gauge sensors: $a$-mean stresses of reinforcement; $b$-relative strain of compressed concrete in the sample P-1.

During the conducted studies of joints between hollow-core slabs and cross-beams brittle failure of the joint connection occurred at the load of $20-24 \mathrm{kN}$ resulting from formation of critical crack on the upper tensile surface of the hollow-core slab fragment at the place where solid connector ends. This fact indicates sufficient stiffness of key joint of the hollow-core slab with precast cross-beam. The reason why further withstanding of the load is impossible is absence of reinforcement of the upper slab part. Insignificant opening of the upper part of junction node of cast-in-place and precast reinforced concrete was recorded at the load of $12 \ldots 16 \mathrm{kN}$ (the last but one stages of loading).

Stresses in longitudinal reinforcement of keys, relative strain of concrete in the upper (tensed) surface of the cross-beam and the slab nearby the joint between hollow-core slab and cast-in-place part of the cross-beam, as well as concrete strain of the lower surface of the slab do not reach admissible standard values. It is well observed from the data of strain gauge sensors, as well as from visual inspection. Numerical simulation of joint connection of the slab with the cross-beam shows the similar fracture pattern. The formation of critical crack is also observed, resulting in fast further fracture in the hollow-core floor slab in the area where concrete key ends, i.e. the place where there is no reinforcement of the upper tensile zone. Ultimate breaking load was $20 \mathrm{kN}$; this value is $17 \%$ less than the experimental data. 


\section{Conclusion}

Conducted experimental and numerical research and the data obtained herein qualitatively and significantly enlarge the existing materials on description of the stress-strain state of precast buildings. Moreover, as specified in the objective of the given work the obtained data enables to accurately assess the structural reliability of pre-fabricated frame of Saret type (with precast cross-beams and hollow-core floor slabs). The following conclusions can be made:

1. Precast buildings which are designed and built in accordance with the Saret system correspond to the required parameters of the $1^{\text {st }}$ and $2^{\text {nd }}$ groups of ultimate behavior, as defined by the technical prescriptions;

2. The span between vertical load bearing elements up to $4.5 \mathrm{~m}$ provides significant reserve of load bearing capacity, stiffness and crack resistance, thus increasing the structural costs;

3. Results of testing joints of cross-beam with the column and slab with the crossbeam showed that this structural solution has some drawbacks; however, they were not defined during field tests on the buildings under construction due to small size of actual spans $(4.5 \mathrm{~m})$ of cross-beams and slabs and overestimated stiffness parameters of horizontal load-bearing elements. Still, civil designers and builders will face these drawbacks when trying to enlarge the spans. Rather rigid connection of hollow-core floor slab with the crossbeam can be referred to one of the mentioned drawbacks leading to the following possible negative consequences:

a. occurrence of tensile stresses the slab in the lateral direction during inclusion of the hollow-core slab into the process of cross-beam deformation, then resulting in formation of longitudinal cracks in it;

b. occurrence of support bending moment in the hollow-core slab in longitudinal direction with further cracks formation in the place of concrete key ending (the slab does not have upper reinforcement).

The following measures can be recommended in order to optimize the structural solution of pre-fabricated frame based on the conducted research:

- construction of flooring with larger span, linking closely the parameters of the existing load-bearing capacity of separate structural elements (slabs and cross-beams) and stresses from external load. Currently, the spans of load bearing horizontal elements up to $4.5 \mathrm{~m}$ provide significantly overestimated and at the same time unreasonable strength reserve of slabs and cross-beams (there are cases when hollow-core slabs reinforced with pre-stressed rebars $7 \varnothing 12 \mathrm{~K} 1500$ cover the spans of $1.8 \mathrm{~m}$, and the cross-beams $450 \mathrm{~mm}$ high and reinforced with pre-stressed rebars 3-4Ø12K1500 cover the spans of $3.0 \mathrm{~m}$ );

- application of upper longitudinal and lateral reinforcement in hollow-core slabs (at least in the support zone) with the aim of withstanding tensile stresses caused by existence of key connection (which is quite rigid).

Experimental and numerical studies show that cast-in-place structures require optimization in order to find the most effective structural solution.

\section{References}

1. V.A. Shembakov, Sborno-monolitnoe karkasnoe domostroenie. Rukovodstvo $k$ prinyatiyu resheniya [Cast-in place and Precast Frame House-Building. Guidance for Decision-Making] (2005) (in Russian)

2. N.V. Nikitin, P.I. Franov, E.M. Timonin, Rekomendatsii po proektirovaniyu konstruktsii ploskogo sborno-monolitnogo perekrytiya "Sochi" [Recommendations 
for Structural Design of a Flat Precast-Cast-In-Place Slab "Sochi”] (1975) (in Russian)

3. A.I. Mordich, V.N. Belevich, V.N. Simbirkin, D.I. Navoi, A.N. Mironov, V.P. Raichev, A.I. Chubrik, Effektivnye konstruktivnye systemy mnogoetazhnykh zhilykh domov I obschestvennykh zdanii (12...25 etazhei) dlya uslovii stroitelstva $v$ Moskve $i$ gorodakh Moskovskoi oblasti, naibolee polno uovletvoryauschie sovremennym marketingovym trebovaniyam [Effective Structural Systems of Multistory Blocks of Flats and Civil Buildings (12..25 Stories) for Construction Conditions in Moscow and the Cities of Moscow Region, Fulfilling Modern Marketing Demands More Completely] (2002) (in Russian)

4. A.I. Mordich, Sborno-monolitnye i monolitnye karkasy mnogoetazhnykh zdanii s ploskimi raspornymi perekrytiyami. Montazhnye i spetsialnye raboty v stroitelstve [In-cast and Precast Joists and Cast-In-Place Frames of Multi-Storey Buildings with Flat Space Slabs], 8-9 (2001) (in Russian)

5. A.S. Semchenkov, Concrete and Reinforced Concrete, 4 (2008) (in Russian)

6. A.S. Semchenkov, Concrete and Reinforced Concrete, 6 (2010) (in Russian)

7. A.M. Kimberg, Effektivnaya konstruktivnaya sistema karkasno-panel'nykh zdaniy s natyazheniem armatury v postroechnykh usloviyakh [Effective Structural System of Frame-Panel Buildings with Tensioning of the Steel in Site Conditions] (TbilZNIIEP Publ., Tbilisi, 1985) (in Russian)

8. B. Koprivitsa, Zhilishchnoe Stroitel`stvo [Housing Construction], 1, (1984) (in Russian)

9. A.I. Mordich, V.N. Belevich, V.N. Simbirkin, D.I. Navoy, BST - Bulletin of Construction Equipment, 8, (2004) (in Russian)

10. A.I. Mordich, V.E. Sadokho, I.I. Podlipskaya, N.A. Taratynova, Concrete and Reinforced Concrete, 5, (1993)

11. A.I. Mordich, S.L. Galkin, Stroitelnaya Nauka i Tekhnika [Construction Science and Technology], 3, (2011) (in Russian)

12. A.S. Semchenkov, Concrete and Reinforced Concrete, 4, (1993) (in Russian)

13. A.S. Semchenkov, A.K. Khavkin, B.S. Sokolov, Concrete and Reinforced Concrete, 6, (2008) (in Russian)

14. A.S. Semchenkov, Concrete and Reinforced Concrete, 1, (2009)

15. L.N. Zaitsev, V.V. Ivanov, V.L. Zaitseva, Concrete and Reinforced Concrete, 2, (2009) (in Russian)

16. V.M. Mitasov, A.A. Koyankin, News of higher educational institutions. Construction, 3, (2014)

17. A.A. Koyankin, V.M. Mitasov, Vestnik MGSU (Scientific and Engineering Journal for Construction and Architecture), 5, (2015) 